\title{
A Study on The Effect of Type of Solvent on Chitosan Efficiency for Treatment of Drinking Water Contaminations
}

\author{
Amira Fouda ** , M.H.M. Hussein*, M. Mursy, M.M. Hazzaa, \\ A.F. Shaban and H.H.H. Hefni*\# \\ Chemistry Department, Faculty of Science, Banha University, \\ Banha City, "Polymers Lab, Petrochemicals Department, \\ Egyptian Petroleum Research Institute (EPRI), Cairo and \\ **Holding Company for Water and Wastewater in Menoufia, \\ Menoufia, Egypt.
}

\begin{abstract}
T $\mathrm{N}$ this research, chitosan $(\mathrm{Ch})$ a natural polymer, was employed in drinking raw water treatment of Nile River against Escherichia coli via simple method, it is dissolution of chitosan in three different solvents;acetic acid (AC),malonic acid (MA) and N carboxymethyl N,N diethylbenzene ammonium chloride (CMEBAC) to produce three different solutions; Ch-AC, Ch-MA and Ch-CMEBAC, respectively. These solutions were characterized by FTIR and elemental analysis. The investigations of their effect against total coliform bacteria of raw water were carried out according to method of Most Probable Number (MPN) at different contact times (30,60 and $120 \mathrm{~min})$. The results showed that the full inhibition of total coliform were achieved after $30 \mathrm{~min}$ as contact time by $7 \mathrm{gm} \mathrm{L}^{-1} \mathrm{ml}$ of Ch-Ac, $5 \mathrm{gm} \mathrm{L}^{-1}$ of Ch-Ma and $0.75 \mathrm{gm} \mathrm{L}^{-1} \mathrm{ml}$ of Ch-CMEBAC. Otherwise, by increasing of contact time, the volumes of inhibitors (chitosan solutions) decrease.The minimum inhibitory concentration (MIC) values of those solutions were detected as $2.75,2$ and $0.2 \mu / \mathrm{ml}$, respectively.
\end{abstract}

Keywords: Chitosan, E.coli, Biological treatment of water and Malonic acid .

Water is one of nature's most important gifts to mankind which is essential to life. Water is a major component of all organisms, the matrix of all processes in living organism that serves as a lubricant in digestion and almost all other bodyprocesses, lubricates our joints and cartilages,moves within our cellular systems transporting vital blood plasma and functioning in regulation of body temperature $^{(1)}$. Body dehydration can lead to death.

Fecal contamination of water is a serious problem due to the potential risk for contracting diseases from pathogens and here exists the need of testing for indicator organisms such as coliform bacteria. To get rid of this problem, disinfection is applied to prevent the growth of pathogenic organisms and to protect public health ${ }^{(2)}$. Different methods of disinfection were handled beginning with sedimentation to chlorination, ozone, UV, chlorine dioxide, potassium

${ }^{\#}$ Corresponding author: hassanhefni@yahoo.com. 
permanganate, nanofiltration, hydrogen peroxide, solar disinfection, organic acids and biological treatment. The most common disinfection method involves some form of chlorine or its compounds such as chloramine or chlorine dioxide. Upon using chlorine certain forms of chlorine react with organic material, naturally present in many water sources, to form harmful chemical by-products. Application of a less or no harm disinfection methods paved to use biopolymers such as chitosan.

The Gram-negative bacterial (E. coli) outer membrane contains polyanionic lipopolysaccharide stabilized by divalent cations, such as $\mathrm{Mg}^{2+}$ and $\mathrm{Ca}^{2+(3)}$. The $\mathrm{OM}$ serves as an effective permeability barrier to restrict macromolecules and hydrophobic substances from entering or leaving bacterial cells ${ }^{(4)}$. The cationbinding sites of lipopolysaccharide are critical to outer membrane integrity. However, cationic substances, known as membrane permeabilizers, e.g., polymyxin and aminoglycosides (chitosan), can compete with divalent cations to bind with lipopolysaccharide, therebydisorganizing the outer membrane structure ${ }^{(5)}$.

Organic acids are preferable to use in water treatment, it's more safe than mineral acids to inhibit the germination of the spores in water ${ }^{(6)}$ and not react with metals. However, the mineral acids are highly reactive with metals, and they have corrosive ability than the organic acids.

Chitosan has a number of unique properties such as antimicrobial activity, nontoxicity, and biodegradability ${ }^{(7)}$. It has a broad spectrum of antimicrobial activities $^{(8)}$, high bactericidal rates $^{(9)}$ and low toxicity toward mammalian cells,making it a potential biocide in food preserving ${ }^{(10)}$ which reflects its administration through oral route. As result of all this we came up with using chitosan as an antimicrobial in water treatment. The antimicrobial activity of chitosan against a variety of bacteria and fungi coming from its polycationicnature is well known ${ }^{(11)}$. However, this activity is limited to acidic conditions due to its poor solubility above pH6.5 ${ }^{(12)}$. Non-chemically modified chitosan must be dissolved in acid solvents to activate its antibacterial activity ${ }^{(10)}$.

As a result we prepared three solutions of chitosan using acetic acid $2 \%, \mathrm{~N}$ (carboxymethyl)-N,Ndiethyl benzene ammonium chloride $2 \%$ and malonic acid $1 \%$ as solvents creating acidic media that favour its antimicrobial activity. Potential applications of chitosan as a bactericide in water treatment were examined recently ${ }^{(13)}$. Raw water samples were collected, physically, chemically and bacteriologicaly examined then treated with different consequent amounts of each solution separately and tested for the effect they had on bacterial growth of total coliform group.

The three solutions were proved to have an inhibitory effect on total coliform bacteria that varied from one solution to another and that effects were studied at different contact times proving that increasing contact time could increase the antimicrobial effect.

Egypt. J. Chem. 57, No.4 (2014) 


\section{Materials and Methods}

Materials

Chitosan was prepared from shrimp shells that were commercially obtained. Molecular weight of chitosan was equal to $109.050 \mathrm{kDa}$. $\mathrm{NaOH}$, acetone, ethyl alcohol and acetic acid were purchased from Adwic, while $\mathrm{HCl}$ was from Panreac. N,N diethyl aniline, monochloro acetic acid and malonic acid were purchased from Aldrich. Agar media was purchased from EDM but Lauryl sulfate broth media was from Merck KGaA. Brilliant green Bile $2 \%$ broth media was a product of Lab M Limited while both EC broth media and M endo agar media were purchased from Becton, Dickinson and Company. Sterillized segmented membrane filter papers were produced by PALL Corporation, while cellulose filtration papers by Ahlstorm.

\section{Method}

i. Preparation of chitin and chitosan from shrimp shells

Chitin and chitosan were prepared from shrimp shells according to the following references ${ }^{(14,15)}$.

ii. Preparation of $N$ carboxymethyl $N, N$ diethyl benzene ammonium chloride (CMEBAC).

CMEBAC was prepared and characterized as in the reference ${ }^{(16)}$.

\section{iii. Preparation of chitosan solutions}

Three solutions of chitosan were prepared by dissolving $2 \mathrm{gm}$ of grinded chitosan in each of acetic acid $2 \%$, malonic acid $1 \%$ and CMEBAC $2 \%$ solvents, respectively to give solutions $\mathrm{Ch}-\mathrm{Ac}, \mathrm{Ch}-\mathrm{Ma}$ and $\mathrm{Ch}-\mathrm{CMEBAC}$.

\section{Characterization of prepared compounds}

\section{i. FTIR}

Chitosan and its derivatives sample $(2 \mathrm{mg})$, which was dried overnight at $60^{\circ} \mathrm{C}$ under reduced pressure, was mechanically well-blended with $100 \mathrm{mg}$ of $\mathrm{KBr}$. The thickness of the $\mathrm{KBr}$ disk was $0.5 \mathrm{~mm}$. The $\mathrm{KBr}$ disk of the mixed powder was desiccated for $24 \mathrm{hr}$ at $110^{\circ} \mathrm{C}$ under reduced pressure and then its IR spectrum was recorded with a Shimadzu FTIR-4200 spectrometer using a disk of $100 \mathrm{mg} \mathrm{KBr}$ as a reference. The intensity of maxima of the IR absorption band was determined by the baseline method.

\section{ii. Elemental analysis of the three solutions}

Chitosan and its derivatives sample were dried at $60^{\circ} \mathrm{C}$ and subjected to the elemental analysis at the National Research Centre in the Organic Microanalyses Section via Vario Elementar that is manufactured in Germany.

\section{Characterization of raw water samples}

The characterization of collected raw water samples were 6.98NTU as turbidity value at $25^{\circ} \mathrm{C}, \mathrm{pH} 7.44$, conductivity $323 \mu \mathrm{S} / \mathrm{cm}$, TDS $203 \mathrm{mg} / \mathrm{L}$, 
alkalinity $132 \mathrm{mg} / \mathrm{L}$, total hardness $(\mathrm{TH}) 132 \mathrm{mg} / \mathrm{L}$, calcium hardness $(\mathrm{CaH}) 88$ $\mathrm{mg} / \mathrm{L}$, magnesium hardness $(\mathrm{MgH}) 44 \mathrm{mg} / \mathrm{L}$, chloride $14 \mathrm{mg} / \mathrm{L}, \mathrm{Fe}$ concentration $0.46 \mathrm{mg} / \mathrm{L}, \mathrm{Mn}$ concentration $0.05 \mathrm{mg} / \mathrm{L}, \mathrm{NH}_{3} 0.05 \mathrm{mg} / \mathrm{L}$ and $0.12 \mathrm{mg} / \mathrm{L}$ as phosphates concentration value.

Estimation of bacterial density of the raw water samples as a Most Probable Number (MPN) value

Bacterial density in raw water samples after and before treatment ware performed through a series of decimal dilutions (five $10 \mathrm{ml}$, five $1 \mathrm{ml}$ and five 0.1 $\mathrm{ml}$ volumes of samples). MPN value was determined through the combinations of positive and negative results.It was detected as $8400 \mathrm{MPN} / 100 \mathrm{ml}$ for raw water before treatment.

Treatmentof raw water samples by chitosan solutions

One liter of raw water, which was previously tested for its Most Probable Number (MPN) value, is treated with different concentrations $\left(\mathrm{mg} \mathrm{L}^{-1}\right)$ from three chitosan solutions at 30,60 and 120 min.

Determination of MIC of chitosan solutions against total coliform bacteria and E.coli

Minimum inhibitory concentration (MIC) is the lowest concentration to cause an inhibition of a certain organism or a group of microorganisms. It was performed according to Kirby-Bauer disk-diffusion method ${ }^{(17)}$ using small filter paper discs labeled in a manner that each labeled disc represented a certain concentration. As for test against total coliform bacteria, mEndo agar media was used as the cultured media and the discs were placed over a $45 \mu$ dimensioned filter paper on which a positive sample was filtered.

As for E.coli, nutrient agar was used and a freshly prepared plate was swapped with a fresh lobe loaded with E.coli. Impregnated discs were placed on and the test was proceeded as a normal Kirby-Bauer disk-diffusion technique giving the first inhibition zone around the disc representing the MIC value.

\section{Results and Discussion}

FTIR data

Figure 1 shows the IR data of chitosan virgin, Ch-AC, Ch-MA and ChCMEBAC. The spectrum of chitosan virgin show the broad and strong band ranging from 3200 to $3600 \mathrm{~cm}^{-1}$ regards to the presence of $\mathrm{OH}$ and $\mathrm{NH}_{2}$ groups, which is consistent with the peaks at 1074 and $1152 \mathrm{~cm}^{-1}$ assigned to alcoholic C-O and C-N$\mathrm{H}$ stretching vibration. The peaks at 2920 and $2875 \mathrm{~cm}^{-1}$ assigned to asymmetric and symmetric $\mathrm{CH}_{2}$ groups. The peaks at 1590 and $1430 \mathrm{~cm}^{-1}$ are characteristic of $\mathrm{NH}_{2}$ and $\mathrm{CH}_{2}$ deformation, respectively. The small peak at $1235 \mathrm{~cm}^{-1}$ attributed to the C-O-C stretching ${ }^{(18)}$.

Egypt. J. Chem. 57, No.4 (2014) 


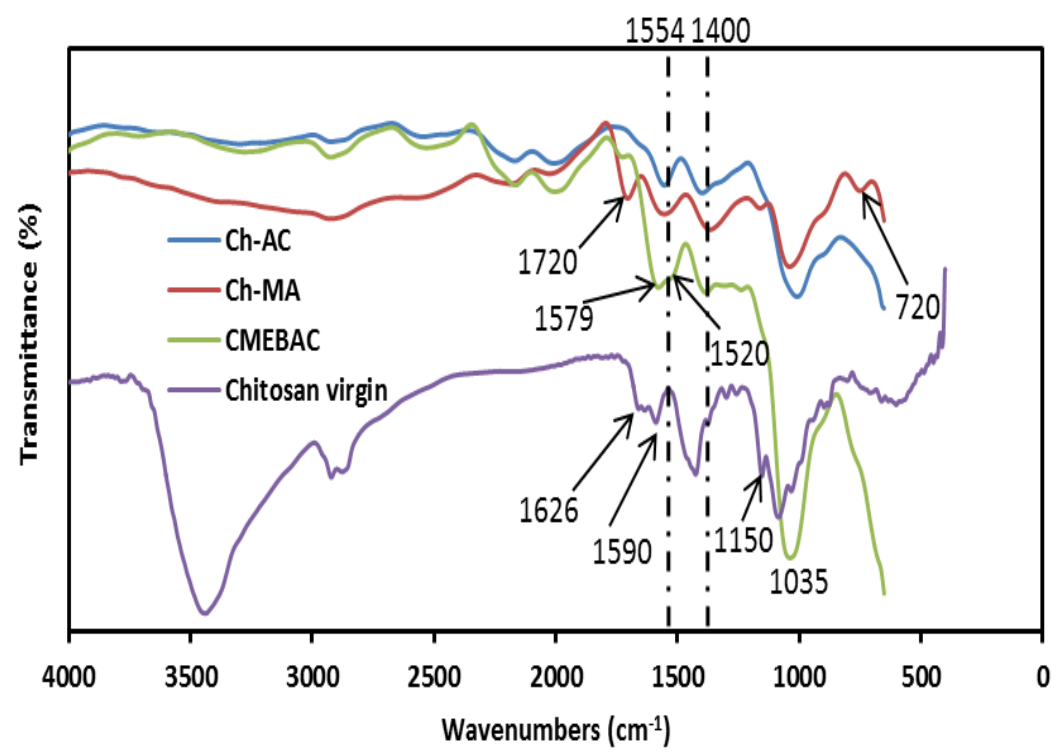

Fig. 1. FT-IR of chitosan and its solutions.

In the spectrum of $\mathrm{Ch}-\mathrm{AC}$, the peaks of $\mathrm{NH}_{2}, \mathrm{NH}_{2}$ deformation and $\mathrm{C}-\mathrm{N}-\mathrm{H}$ groups at 3450,1590 and $1152 \mathrm{~cm}^{-1}$, respectively disappeared, attributed to the protonation of all $\mathrm{NH}_{2}$ groups to $\left(\mathrm{NH}_{3}{ }^{+}\right)$groups. While the strong peak at $1550 \mathrm{~cm}^{-1}$ and a weak peak near $1400 \mathrm{~cm}^{-1}$ region appeared which are attributed to asymmetric and symmetric carboxylate anion stretching. These peaks provide evidence of the conversion of chitosan to chitosan acetate ${ }^{(19,20)}$.

While the Ch-MA spectrum show the same change of peaks of the Ch-AC spectrum, in addition, appearance of two peaks, at $1720 \mathrm{~cm}^{-1}$ due to the ester carbonyl $(\mathrm{C}=\mathrm{O})$ stretching vibrations, which is related to the two carboxylic groups of MA in the specimen ${ }^{(21)}$, and the peak at $720 \mathrm{~cm}^{-1}$ regarding to $\mathrm{CH}_{2}$ rocking of $\mathrm{MA}^{(22,23)}$.

As for spectrum of Ch-CMEBAC also present the similar changes of Ch-AC, as well as, the appearance of broad peak between 1600 and $1500 \mathrm{~cm}^{-1}$ which are attributed to two peaks of $\mathrm{C}=\mathrm{C}-\mathrm{C}$ of aromatic ring stretch at 1579 and $1520 \mathrm{~cm}^{-1(24)}$, and the peak of the asymmetric carboxylate anion stretching at $1550 \mathrm{~cm}^{-1}$. Also, the increasing of the intensity of peak at $1007 \mathrm{~cm}^{-1}$, due to the C-C stretching of diethyl groups ${ }^{(25)}$.

\section{Elemental analysis of the three solutions}

Table 1 shows the Elemental analysis of all prepared compounds, the results illustrate that the percentages of the elements vary from compound to an other, indicating to the formation of the compounds. 
TABLE 1. The elemental analysis of chitosan and its solutions.

\begin{tabular}{|c|c|c|c|c|}
\hline Compound name & $\mathbf{C \%}$ & $\mathbf{H \%}$ & $\mathbf{N \%}$ & $\mathbf{C l \%}$ \\
\hline Chitosan virgin & 39.88 & 4.63 & 7.26 & - \\
\hline Ch-AC & 63.1 & 8.25 & 5.2 & - \\
\hline Ch-MA & 37.4 & 7.89 & 4.47 & - \\
\hline Ch-CMEBAC & 33.15 & 7.76 & 4.88 & 9.1 \\
\hline
\end{tabular}

\section{Inhibition mechanism of chitosan solutions}

The solutions under this study possess two parts, chitosan and organic acids. Chitosan free (powder or flaks) has antibacterial activity for E. coli involve disrupt the barrier properties of the outer membrane ${ }^{(26,27)}$ through the free amino groups which interact against waterborne pathogens. Otherwise the introduction of a large amount of $-\mathrm{OH}$ from chitosan may chelate metal elements such as $\mathrm{Ca}$ in cell membrane ${ }^{(28)}$.

While the organic acids possess two functions as antimicrobial agents. The primary action is through $\mathrm{pH}$ depressions, which give the ability of organic acids to change from undissociated to dissociated form, makes them effective antimicrobial agents ${ }^{(29,30)}$. When an organic acid is in the undissociated form, it can freely diffuse through the semi-permeable cell wall of microorganisms into their cell cytoplasm. Once inside the cell, where the $\mathrm{pH}$ is maintained near 7, the acid will dissociate and $\mathrm{pH}$ will decrease, thus disturbing and finally killing the microorganism ${ }^{(31)}$. The secondary action is the anionic part of the organic acids (carboxylic groups) that cannot escape the bacteria in its dissociated form will accumulate within the bacteria and disrupt many metabolic functions, leading to osmotic pressure increase, incompatible with the survival of the bacteria ${ }^{(32-34)}$.

When, chitosan mix with organic acid solutions a several quaternary ammonium groups are produced in the backbone of chitosan which are responsible for the antimicrobial action as shown in Schemes (1-3). There were two possibilities explaining the antibacterial action of chitosan solutions ${ }^{(35)}$, (1) chitosan solutions might interact with and interactive some contents in the broth (media) by the method of ionic interaction ${ }^{(36)}$ and (2) the bacteria could adhere to each other through the positive charges on chitosan chains which adsorbed on their surfaces, caused disruption of cell membranes ${ }^{(35,37,38)}$.

The adsorbed positively charged of chitosan solutions (quaternary ammonium groups) interacts and forms polyelectrolyte complexes with negatively charged of acidic polymers (polyanionic lipopolysaccharide) produced at the bacterial cell surfaces causing the leakage of proteinaceous and other intracellular constituents ${ }^{(39)}$. The mechanism of this interaction could be explained in the following sequence, (i) adsorption and penetration of the quaternary ammonium groups into the cell

Egypt. J. Chem. 57, No.4 (2014) 
wall; (ii) reaction with the cytoplasmic membrane (lipid or protein) followed by membrane disorganization; (iii) leakage of intracellular low-molecular-weight material; (iv) degradation of proteins and nucleic acids; and (v) wall lysis caused by autolytic enzymes ${ }^{(40-42)}$. There is thus a loss of structural organization and integrity of the cytoplasmic membrane in bacteria, together with other damaging effects to the bacterial cell.

\section{Effect of solvents}

The antimicrobial activity of chitosan solutions with different contact times (30, 60 and 120) are present in the Fig. 2, 3, 4, respectively, it's clear from this figures that the antimicrobial activity of Ch-CMEBAC is higher about $\mathrm{Ch}-\mathrm{AC}$ and Ch-MA, and gave the full inhibition of E. coli at $1.25 \mathrm{gm} \mathrm{L}^{-1}$ after $30 \mathrm{~min}$, this attributed to its chemical structure which contains many influencing groups possess antimicrobial activity as can be seen in Scheme (1), such as, benzene ring, carboxylic group, chlorine ions and alkyl chains (two ethyl groups) which could form a layer of film around cells to affect the absorption of nutrients, and make the CMEBAC in more proximity to the cell membrane ${ }^{(28)}$, as well as, two quaternary ammonium $\left(\mathrm{N}^{+}\right)$groups that has cationic nature to facilitate the bonding to negative sites on the cell wall of bacteria, and also it has mycobacteriostatic action ${ }^{(43,44)}$, as mentioned above.These groups support and increase the efficiency of Ch-CMEBAC to E. coli.

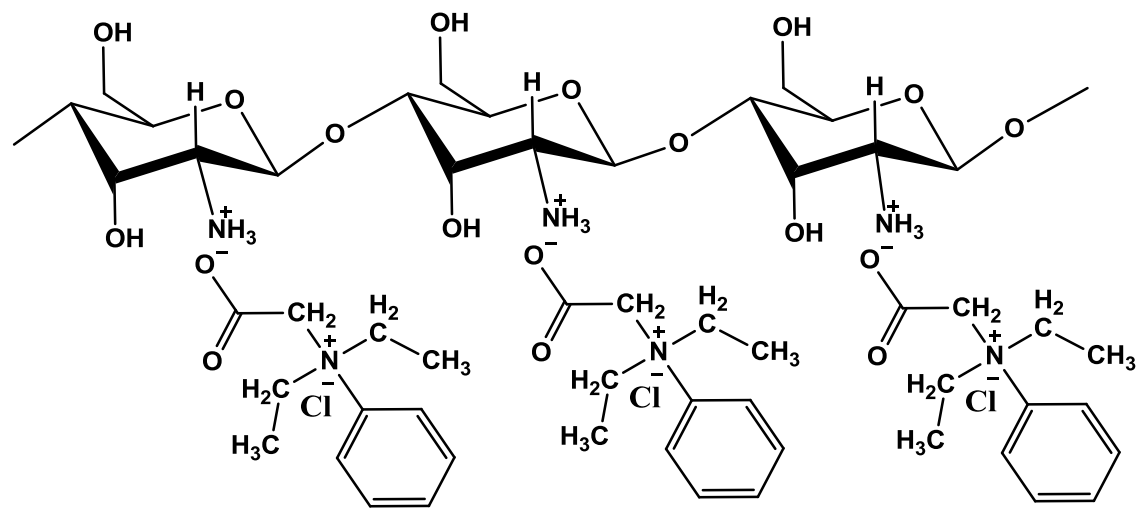

Scheme 1. Chitosan in N-(Carboxy methyl)-N,N-diethyl benzen ammonium chloride (CMEBAC).

While the Ch-MA has a medium antimicrobial effect, it exhibits the full inhibition at $5 \mathrm{gm} \mathrm{L}^{-1}$ after $30 \mathrm{~min}$, due to the bi-functional organic acids (two carboxylic groups) which give a strong dissociation of the solution, and appear to exert their disinfectant action in the manner of themineral acids, mostly through the hydrogen ion ${ }^{(30)}$. Moreover, malonic acid binds between chitosan chains as can be seen in Scheme (2) to allow the attack of E.coli to be by two $\mathrm{NH}_{3}{ }^{+}$groups in one time ${ }^{(45)}$. 


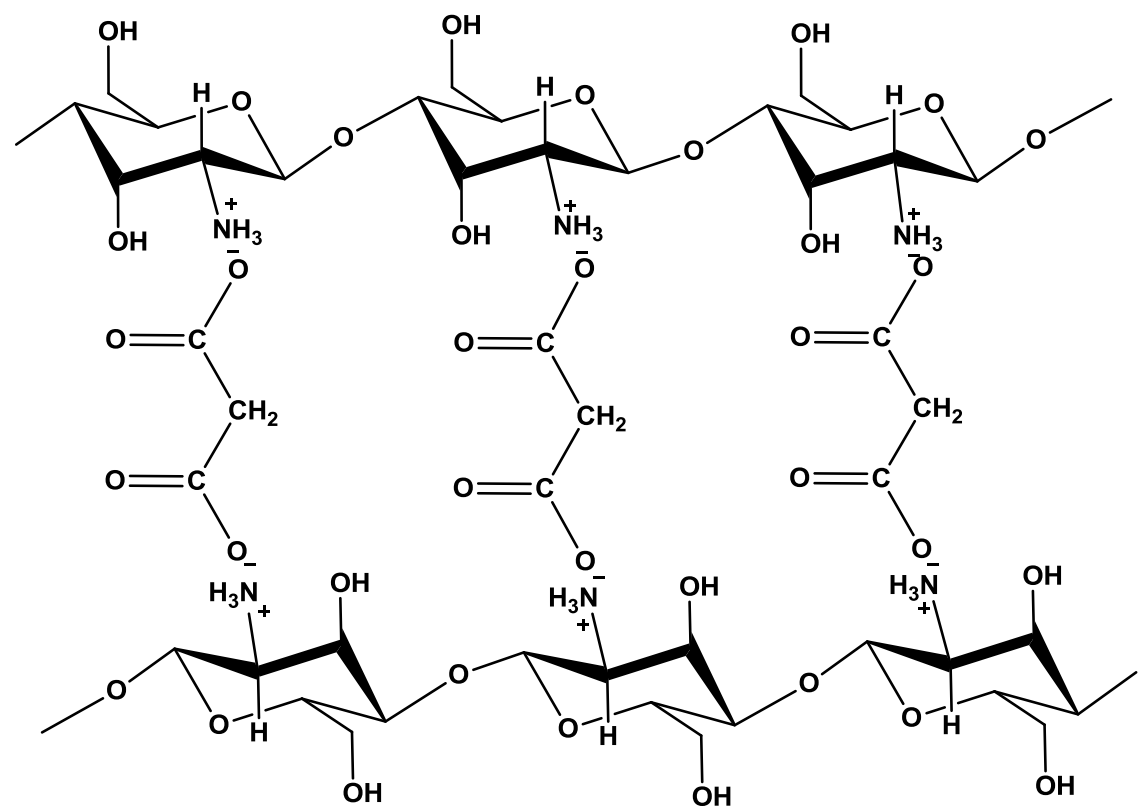

Scheme 2 . Chitosan in malonic acid.

However, the $\mathrm{Ch}-\mathrm{AC}$ exhibit a lower antimicrobial affect about $\mathrm{Ch}-\mathrm{CMEBAC}$ and Ch-MA, it gives a full inhibition at $7 \mathrm{gm} \mathrm{L}^{-1}$ after $30 \mathrm{~min}$, due to containing a one $\mathrm{NH}_{3}^{+}$group and one carboxylate ion and also lower degree of disposition, as can be seen in Scheme (3).

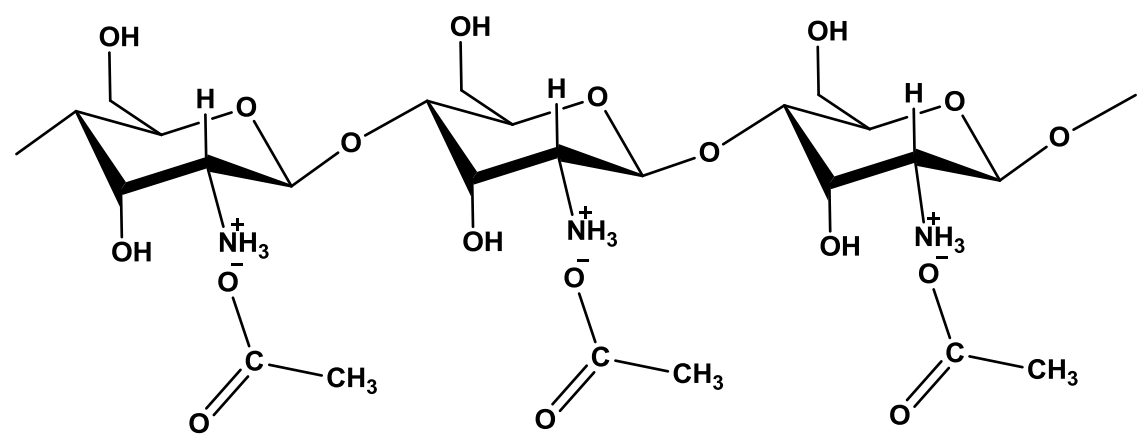

Scheme 3. Chitosan in acetic acid.

Effect of contact time

Figures 2-4 show the antimicrobial activity of chitosan solutions with contact time, it's clear that by increasing contact time the antimicrobial activity of chitosan solutions, increase as in the literature ${ }^{(46-47)}$. 


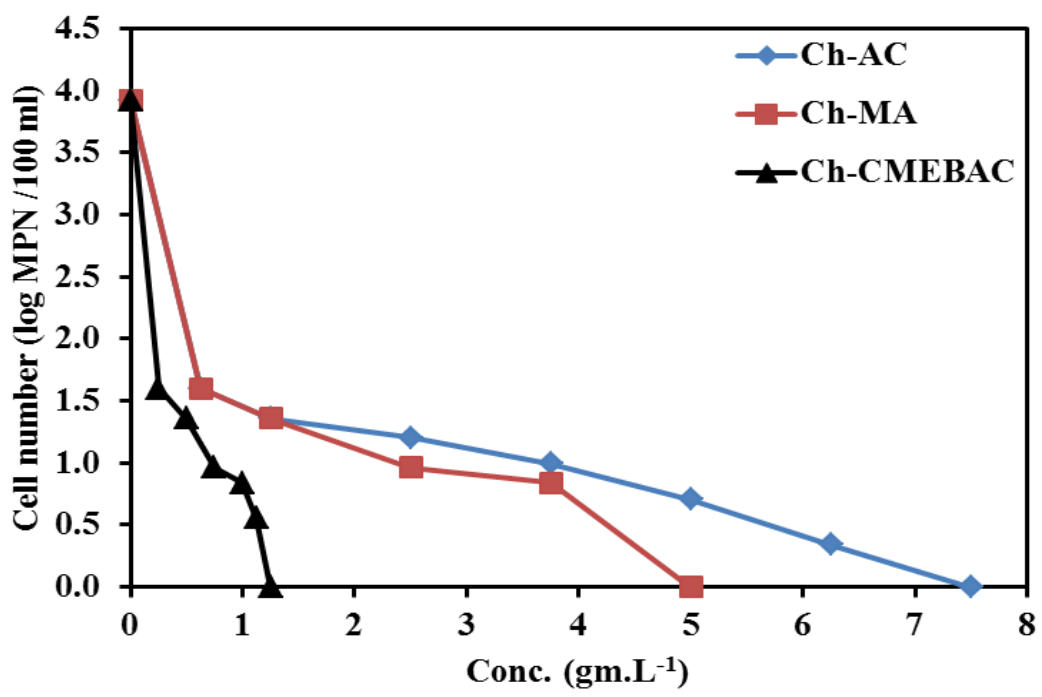

Fig. 2. Inhibition of E.coli by chitosan solutions at contact time $30 \mathrm{~min}$.

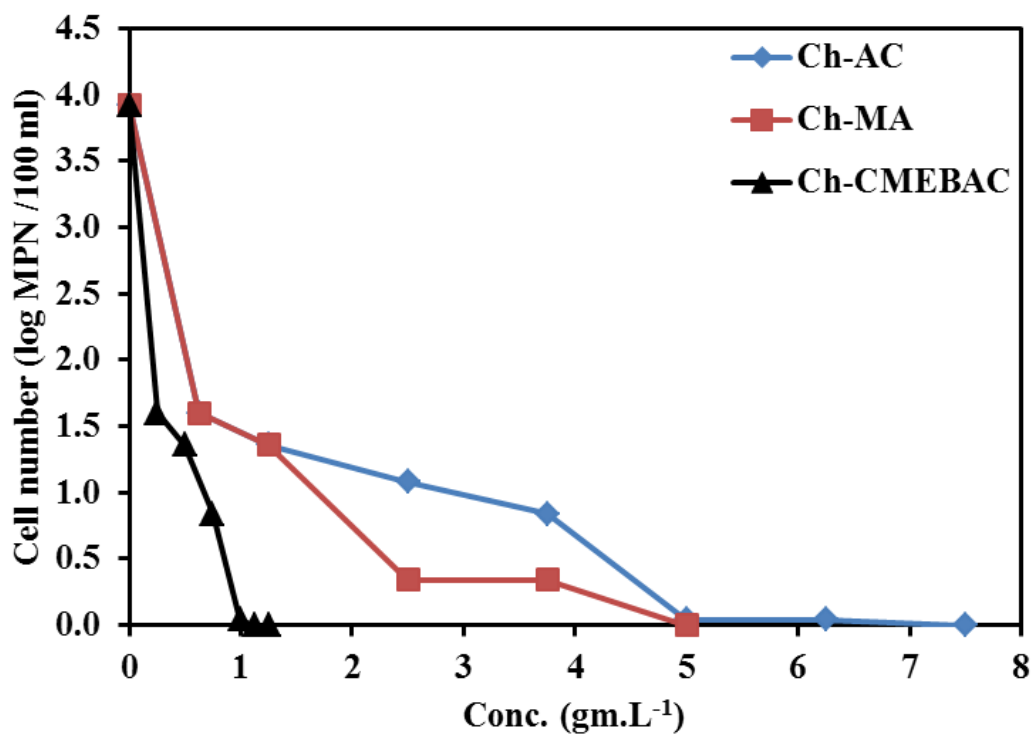

Fig. 3. Inhibition of $E$.coli by chitosan solutions at contact time $60 \mathrm{~min}$. 


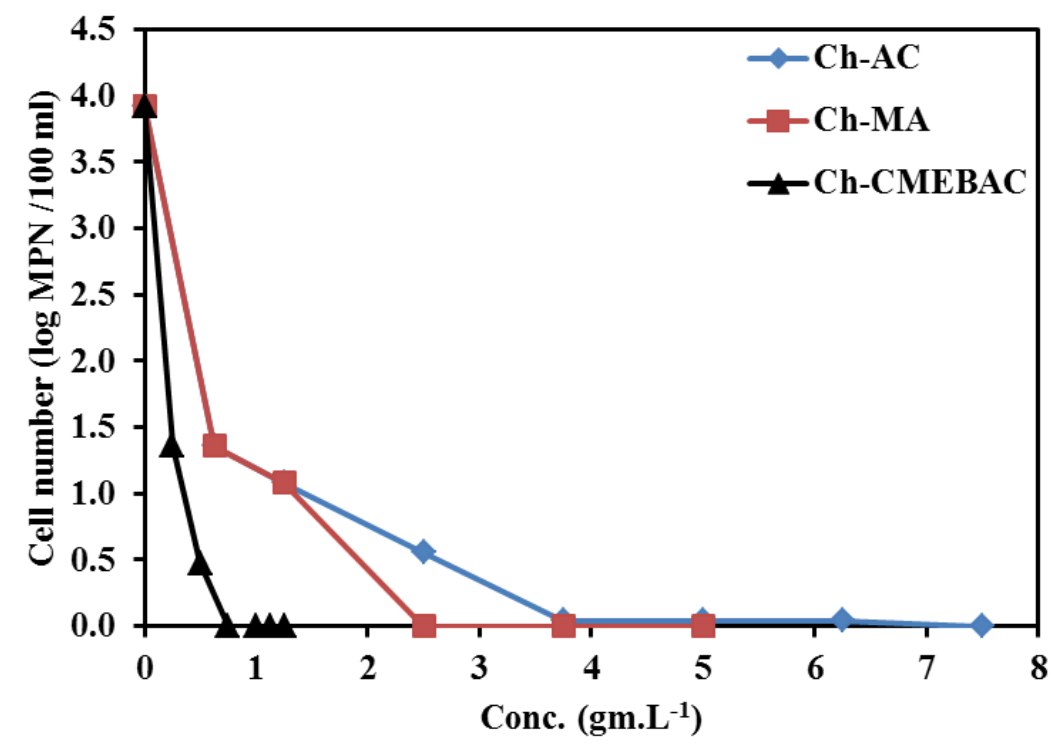

Fig. 4. Inhibition of E.coli by chitosan solutions at contact time $120 \mathrm{~min}$.

The MIC of chitosan solutions against total coliform group of bacteria

For Ch-Ac, the MIC was $2.75 \mu \mathrm{g} / \mathrm{ml}$, while Ch-CMEBAC the MIC was much less than for Ch-Ac declaring a better effect and inhibited at $0.2 \mu \mathrm{g} / \mathrm{ml}$. Ch-Ma had a concentration about $2 \mu \mathrm{g} / \mathrm{ml}$.as its MIC.

\section{The MIC of chitosan solutions against E.coli}

E.coli, which is the major organism in the total coliform group, was inhibited at MIC values that are the same as those for the total coliform group. The MIC values of E.coli are as the following, $2.75 \mu \mathrm{g} / \mathrm{ml}$ for Ch-AC, $2.0 \mu \mathrm{g} / \mathrm{ml}$ for Ch$\mathrm{MA}$ and $0.2 \mu \mathrm{g} / \mathrm{ml}$ for Ch-CMEBAC.

\section{Conclusion}

In this work, the drinking raw water of Nile River contains E. coli (8400 MPN/100 ml), were full killed by using ecofriendly materials (chitosan solutions) after contact time $30 \mathrm{~min}$ by $7 \mathrm{gm} \mathrm{L}^{-1}$ of Ch-AC, $5 \mathrm{gm} \mathrm{L}^{-1}$ of Ch-MA and 1.25 $\mathrm{gmL}^{-1}$ of Ch-CMEBAC.

The higher antimicrobial activity of Ch-CMEBAC than other two solutions, regards to the influencing groups and atoms in its structure such as, benzene ring, carboxylic group, chlorine ions, alkyl chains and two quaternary ammonium groups $\left(\mathrm{N}^{+}\right)$other solutions. These solutions depend on their structures. While the lower activity of $\mathrm{Ch}$-AC regards to the poverty in the influencing groups in its structure. 
Acknowledgments : We are grateful for the help of Egyptian Petroleum Research Institute and the Holding Company for Water and Wastewater in Menoufia.

\section{References}

1. http://www.freedrinkingwater.com.

2. http://www.lenntech.com.

3. Vaara, M., Agents that increase the permeability of the outer membrane. Microbiol. Rev. 56, 395-411 (1992).

4. Hancock, REW., The bacterial outer membrane as a drug barrier. Trends Microbiol. 5, 37-42 (1997).

5. Hong Tang, Peng Zhang, Thomas L. Kieft, Shannon J. Ryan, Shenda M. Baker, William P. Wiesmann and Snezna Rogelj, Antibacterial action of a novel functionalized chitosan-arginine against gram-negative bacteria. Acta Biomaterialia, 6, 2562-2571 (2010).

6. Clark, J.F., On the toxic effect of deleterious agents on the germination and development of certain filamentous fungi. Botanical Gazette, 28, 289-327 (1899).

7. Li, Q., Dunn, E.T., Grandmaison, E.W. and Goosen, M.F., Application and properties of chitosan. In : Applications of Chitin and Chitosan. Goosen, M.F.A. (Ed.); Technomic Publishing: Lancaster, PA. pp. 3-29 (1997).

8. Chung, Y.C., Wang, H.L. and Chen, Y.M., Effect of abiotic factors on the antibacterial activity of chitosan against waterborne pathogens. Bioresource Technology, 88, 179-184 (2003).

9. Helander, I.M., Nurmiaho-Lassila, E.L., Ahvenainen, R., Rhoades, J. and Roller, S., Chitosan disrupts the barrier properties of the outer membrane of Gram-negative bacteria. International Journal of Food Microbiology, 71, 235-244 (2001).

10. Roller, S. and Covill, N., The antifungal properties of chitosan in laboratory media and apple juice. International Journal of Food Microbiology, 47, 67-77 (1999).

11. Sudardshan, N.R., Hoover, D.G. and Knorr, D., Antibacterial action of chitosan. Food Biotechnol. 6, 257-272 (1992).

12. Tsai, G.J. and Su, W.H.,Antibacterial activity of shrimp chitosan against Escherichia coli. Journal of Food Protection, 62, 239-243 (1999).

13. Liu, X.F., Guan, Y.L., Yang, D.Z., Li, Z. and Yao, K.D., Antibacterial action of chitosan and carboxymethylated chitosan. J. Appl. Polym. Sci. 79 (7), 1324-1335 (2000).

14. Hussein M.H.M., El-Hady, M.F., Sayed, W.M. and Hefni, H., Preparation of some chitosan heavy metal complexes and study of its properties. Polym. Sci. Ser. A 54 (2), 113-124 (2012). 
15. Hussain, M.H.M., Abdeen, Z. and Hefni, H., Chitosans production byproducts as valuable material. Advances in Chitin Science - XI, Venice, 493-498 (2009).

16. Hussein, M.H.M., El-Hady, M.F., Shehata, H.A.H., Hegazy, M.A. and Hassan H.H.H., Preparation of some eco-friendly corrosion inhibitors having antibacterial activity from sea food waste. J. Surfact. Deterg. 16, 233-242 (2013).

17. Bauer, R.W., Kirby, M.D.K., Sherris J.C. and Turck, M., Antibiotic susceptibility testing by standard single disc diffusion method. American Journal of Clinical Pathology , 45, 493-496 (1966).

18. Kasaai, M.R., A review of several reported procedures to determine the degree of Nacetylation for chitin and chitosan using infrared spectroscopy. J. Carbohydrate Polymers, 71 (4), 497-508 (2008).

19. Hemant, K.S.Y. and Shivakumar, H.G., Development of chitosan acetate films for transdermal delivery of propranolol hydrochloride. Tropical Journal of Pharmaceutical Research, 9 (2), 197-203 (2010).

20. Nunthanid, J., Laungtana-anan, M., Sriamornsak, P., Limmatvapirat, S., Puttipipatkhachorn, S., Lim, L.Y. and Khor, E., Characterization of chitosan acetate as a binder for sustained release tablets. Journal of Controlled Release, 99, $15-26$ (2004).

21. Trina Ghosh Dastidar and Anil N., Netravali, 'Green' crosslinking of native starches with malonic acid and their properties. Carbohydrate Polymers, 90, 16201628 (2012).

22. Svetlana, Z. Rogovina, Galina A. Vikhoreva, Tat'yana A. Akopova, Irina N. Gorbacheva and Sergei N. Zelenetskii, Reactions of chitosan with solid carbonylcontaining compounds under shearing deformation conditions. Mendeleev Communications, 8 (3), 107-109 (1998).

23. Osman, Z. and Arof, A.K., FTIR studies of chitosan acetate based polymer electrolytes. Electrochimica Acta, 48, 993-999 (2003).

24. John Coates, Interpretation of infrared spectra, A Practical Approach, Encyclopedia of Analytical Chemistry, R.A. Meyers (Ed.), pp. 10815-10837, John Wiley \& Sons Ltd, Chichester (2000).

25. El-Nahass, M.M., Zeyada, H.M., Abd-El-Rahman, K.F., Farag, A.A.M. and Darwish, A.A.A., Fourier-transform infrared and optical absorption spectra of 4-tricyanovinyl-N,Ndiethylaniline thin films. Spectrochimica Acta Part A 69, 205-210 (2008).

26. Andres, Y., Giraud, L.C. Gerente and Le Cloirec, P., Antibacterial effects of chitosan Powder: Mechanisms of action. Environmental Technology, 28 (12), 13571363 (2007).

27. Helander, I.M., Nurmiaho-Lassila, E.L., Ahvenainen, R., Rhoades, J. and Roller, S., Chitosan disrupts the barrier properties of the outer membrane of gram-negative bacteria. International Journal of Food Microbiology, 71, 235-244 (2001).

Egypt. J. Chem. 57, No.4 (2014) 
28. Russell, A.D., Activity of biocides against mycobacteria. J. Appl. Bacteriol, Symp. Suppl. 81, 87S-101S (1996).

29. Winslow, C.E.A. and Lochridge, E.E., The toxic effect of certain acids upon typhoid and colon bacilli in relation to the degree of their dissociation. Jour. Inf. Dis. 3 (4), 547-571 (1906).

30. James, D. Reid, The disinfectant action of certain organic acids. Am. J. Epidemiol. 16 (2), 540-556 (1932) .

31. http://www.lignotechfeed.com/SoftAcid/Bacterial-Inhibition Properties/ (language)/ eng-GB.

32. Dibner, J.J. and Butin, P., Use of organic acids as a model to study the impact of gut microflora on nutrition and metabolism. J. Appl. Poultry Res. 11, 453 -463 (2002).

33. Chung, Y.C. and Chen, C.Y., Antibacterial characteristics and activity of acidsoluble chitosan. Bioresource Technology, 99, 2806-2814 (2008)..

34. Hortensia Ortega-Ortiz, Baltazar Gutiérrez-Rodríguez, Gregorio Cadenas-Pliego and Luis Ibarra Jimenezl, Antibacterial activity of chitosan and the interpolyelectrolyte complexes of poly(acrylic acid)-chitosan. Brazilian Archives of Biology and Technology ; An International Journal , 53 (3), 623-628 (2010).

35. Yan Li, Xi Guang Chen, Nan Liu, Cheng Sheng Liu, Chen Guang Liu, Xiang Hong Meng, Le Jun Yu and John F. Kenendy, Physicochemical characterization and antibacterial property of chitosan acetates. Carbohydrate Polymers, 67, 227-232 (2007).

36. Shimojih, M., Fukushima, K. and Kurita, K., Low-molecular-weight chitosans derived from chitin: Preparation, molecular characteristics and aggregation activity. Carbohydrate Polymers, 35, 223-231 (1998).

37. Strand, S.P., Nordengen, T. and Ostgaard, K., Efficiency of chitosans applied for Xocculation of different bacteria. Water Research, 36, 4745-4752. 76, 211-218 (2002).

38. Liu, H., Du, Y.M., Wang, X.H. and Su, L.P., Chitosan kills bacteria through cell membrane damage. International Journal of Food Microbiology, 95, 147-155 (2004).

39. Chung, Y.C., Su, Y.P., Chen, C.C., Jia, G., Wang, H.L. and Wu, J.C.G., Relationship between antibacterial activity of chitosan and surface characteristic of cell wall. Acta Pharmacologica Sinica, 27 (7), 932-936 (2004).

40. Hugo, W.B. and Frier, M., Mode of action of the antibacterial compound dequalinium acetate. Appl. Microbiol. 17, 118-127 (1969).

41. Salton, M.R.J., Lytic agents, cell permeability and monolayer penetrability. J. Gen. Physiol. 52, 277-252 (1968). 
42. Denyer, S.P., Mechanisms of action of antibacterial biocides. Int. Biodeterior. Biodegrad, 36, 227-245 (1995).

43. Hui Liu, Yumin Du, Jianhong Yang and Huayue Zhu, Structural characterization and antimicrobial activity of chitosan/betaine derivative complex. Carbohydrate Polymers , 55, 291-297 (2004).

44. Akpata E.S. and Akinrimisi E.O., Antimicrobial activity of Micromeria nervosa from the Palestinian area. J. Ethnopharmacol. 58, 143-14 (1997).

45. Tapas Mitra, Sailakshmi, G., Gnanamani, A. and Mandal, A.B., Preparation and characterization of malonic acid cross-linked chitosan and collagen 3D scaffolds: an approach on non-covalent interactions. J. Mater. Sci: Mater Med. 23, 1309-1321 (2012).

46. Ying-Chien Chung and Chih-Yu Chen, Antibacterial characteristics and activity of acid-soluble chitosan. Bioresource Technology, 99 , 2806-2814 (2008).

47. Libin Zhu, Jutta Elguindi, Christopher Rensing and Sadhana Ravishankar, Antimicrobial activity of different copper alloy surfaces against copper resistantand sensitive Salmonella enterica. Food Microbiology, 30 , 303-310 (2012).

(Received 29/10/2014

accepted 10/11/2014) 


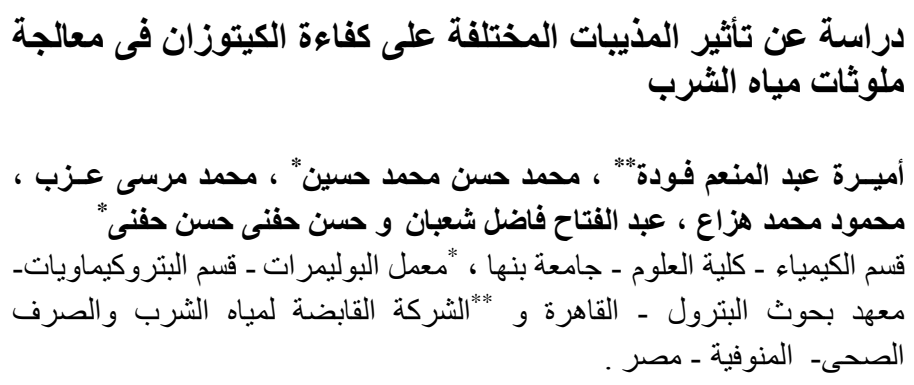

